\title{
A Discursive Analysis of the Gaza Conflict of 2008-09: Provocation and Proportionality in War Reporting
}

\author{
NOUR SHREIM, Independent Scholar
}

\begin{abstract}
The paper employs an interpretative discourse analysis, to investigate the cultural ideas evoked linguistically throughout the coverage of the Gaza War of 2008-09 (Operation Cast Lead). It aims to provide a historical context to better understanding Operation Protective Edge. To allow for a comparative dimension, the paper develops two 'frames' of analysis that systematically look at two recurring themes and scrutinise their discursive strategies and functions in the construction of meaning and ideology. These include Provocation, which examines questions of responsibility and culpability; and Proportionality, which embraces matters of legitimacy and authority in relation to the humanitarian aspect of the war. The findings indicate that the actions of a protagonist may be deemed legitimate with regard to provocation, but illegitimate with regard to their proportionality. The peculiar circumstances of the war pushed the media in the direction of greater separation from the predominant ideologies ensued by the Israeli Army. It suggests that BBC World Service lack a coherent discursive strategy at the level of the lexical in their reporting of Gaza.
\end{abstract}

\section{KEY WORDS}

Gaza War; Palestinan-Israeli Conflict; Critical Discourse Analysis; BBC World Service; Global Journalism 


\section{Introduction}

The Palestinian-Israeli conflict remains one of the most heated and highly debated issues of modern history, it remains so not only in its origins, but in the goals and motivation of each side and the effects it has on Middle-Eastern politics. The media coverage of the latest surge of fighting between Israel and Hamas in the Gaza Strip has been met with criticism from both sides with the Western media being accused of privileging the Israeli narrative over that of the Palestinian. In return, this has seen both sides revive the intense social media battle that was witnessed during the Israeli offensive on the Gaza Strip (Operation Pillar Defence) in 2012. Many Palestinians and Israelis alike took to social media platforms to counter the mainstream narrative of the Gaza Crisis - what has been referred to as the weapon of choice in the conflict. Whilst the increasing use of social media in the reporting of Israel's offensives on Gaza has been well publicised, it is important to understand the role of the television reporting that so often forms its foundation, which is what the following paper will explore. In addition, by looking at Operation Cast Lead, the paper aims to provide a contextualised historical background to the 66 year-old conflict in order to better understand the recent events of 2014. It is particularly concerned with the portrayal of interpretations, motivations and rationale of the Gaza Conflict of 2008-09 (Operation Cast Lead). It examines how war generally, is often depicted as a bargaining failure that misrepresents the problem at stake to serve the objectives of a certain side. Through representation and through discursively and semantically analysing news texts gathered from BBC World News, it aims to answer the following questions: who started the conflict, who is culpable for the destruction and violence, why are 'they' fighting and to whom is agency for these actions and events attributed? It then focuses on the role of language in social life, specifically in understanding the ideologies that underlay the prominent themes presented in this domain.

Using the method of Critical Discourse Analysis (CDA) the paper aims to present two 'frames' of analysis that were bound by the events of the Gaza conflict. It will systematically look at two recurring themes and scrutinize their discursive strategies and functions in the construction of meaning and ideology. These include Provocation, which examines questions of responsibility and culpability; and Proportionality, which embraces matters of legitimacy and authority with regards to the humanitarian aspect of the war.

\section{Journalistic Values and Objectivity -'Can the media tell the Truth?’}

Journalism as a profession is claimed to be an honourable one, regardless of the fact that many of those who should cherish it and care for it - often including its very own professionals - have acted otherwise (Belsey and Chadwick 1992, 1). Governments have either managed to censor and control it, or have actively succeeded in employing PR tactics to manage media opinion, often for their own political gains. Owners, it is argued, have exploited it in order to satisfy their 'quest for power and wealth, not to mention megalomania' (ibid.). Even journalists, have time and time again proven to dishonour the profession, as Belsey and Chadwick $(1992,1)$ remind us, journalists 'do not even need to be bribed to behave unethically'. 
The notion of professionalism - or the question of whether journalism is a bona fide profession (Soloski 1997, 138) - is central to understanding the process by which events are selected for presentation as news. For journalists, objectivity is one of the most important professional norms, and from it follows more specific features of news professionalism including 'news judgement, the selection of sources and the structure of news beats' (ibid, 143). In recent years, however, journalists have indicated that it has become increasingly hard to maintain a wholly 'objective' mode of reporting; instead they "have fallen back to more defensible standards, like "accuracy", "balance", and "fairness", (Reese 1997, 424). Objectivity then becomes, in Tuchman's (1972) terms, a "strategic ritual" by which journalists accused of bias or distortion adopt certain strategies to defend their profession by demonstrating that such news accounts are essentially authentic, that they contain no unjustified connotations or adjectives and adverbs and that statements of opinion are strictly associated with news sources (Ettema et al. 1997, 39). Alternatively, journalists may also attempt to defy questioned news reports by highlighting their individual expertise, talent or ability of reporting (ibid.)

The underlying principle of objectivity specifies that the truth should be implicitly equated with facts and differentiated from value judgements and opinions (Ettema et al. 1997, 35; Schudson 2001; Schudson 1978; Tumber 2004: 201; Soloski 1997: 143; Bird and Dardenne1997, 333), in which the interference of value with the presentation of facts threatens the essence of objectivity (Reese 1997, 424). In a similar manner, objectivity resides in the attitudes and cognitions of the journalist; therefore by adhering to the professional procedures of good journalism, personal opinion becomes of little significance.

The question of the extent to which -or whether at all -journalism embodies truth has been the focus of many scholarly work (e.g. Ettema et al. 1997; Hall 1977; Murdock, 1982), whom regard the medium of mass communication as 'a means for legitimation and maintenance of socioeconomic stratification' (Ettema et al. 1997, 34). Knowing and reporting the truth are the main corresponding goals in journalism. Practitioners and critics alike constantly assert that questioning truth through journalism implies that journalism does seek 'truth -partial, superficial, occasion-and celebrity-centred truth, but truth nevertheless" (Gitlin 1979, 263). In simple terms, this suggests that 'as a practical matter there is truth to be known and told' (Ettema, Whitney and Wackman 1997, 34; emphasis in original). Given that Western standards of news reporting rely on the assumption that 'there is a reality out-there-to-be-described', any effort in denying this premise is termed "propaganda" (Molotch and Lester 1997, 199). Thus, the dividing line between news and propaganda lies in the intention behind the assemblers' work: those intending to put across a certain ideological message produce propaganda whereas those whose only aim is to reflect a veridical picture of reality produce news (ibid.).

With regards to ideology, Tuchman $(1983,33)$ endorsing a materialistic approach, argues that the 'production of culture' is part and parcel of an organisational sociology that through contemporary capitalism 'obscures the historicity of cultural products' and thus helps implicate 'the creation of ideology' (cited in Ettema et al. 1997, 32). In that she encourages attention towards an understanding of ideology as an embedded practice in an organisational process (ibid.). This is evident when common grounds are detected between 'the ruling ideology' at a given time and the 
media content available (Murdock and Golding, 1977 cited in Ettema et al., 1997, 32). Hall (1973), also, suggests that: 'News values appear as a set of neutral, routine practices: but we need also to see formal news values as an ideological structure - to examine these rules as the formalisation and operationalisation of an ideology of news' (p. 77 cited in Eldridge 1995, 49-50).

\section{Critical Discourse Analysis}

The method of Critical Discourse Analysis (henceforth CDA) is designed to facilitate 'in-depth examination of the episodic news framing' (Iyengar, 1991) in which 'meaning' and 'doing' are situated within the context of its usage. It follows that 'in order to properly understand discourse we need to do more than analyse the interrelations of sentences and how they hang together as a cohesive and coherent text. To properly interpret, for example, a press release, or a newspaper report or an advert, we need to work out what the speaker or writer is doing through discourse and how this 'doing' is linked to wider inter-personal, institutional, socio-cultural and material contexts' (Richardson 2007, 24).

Discourse analysis is a broad and complex interdisciplinary field (Fairclough and Wodak 1997; Wodak and Meyer 2001) that differ in theory, methodology and the types and prominence of research issues. Linguistics, anthropology, sociology and semiotic analysis are all part and parcel of the discourse's diverse theoretical and methodological developments. All approaches to discourse, however, share a commitment to studying the use of language in its context. In particular terms, it includes 'a combination of interdiscursive analysis of texts (i.e. of how different genres, discourses and styles are articulated together) and linguistic and other forms of semiotic analysis' (Fairclough 1993, 8).

Critical discourse analysts realise that textual contents, in different contexts, are not born out of thin air but are rather a constructed reality resulted from 'choice': the choice of granting news access to one person over another, the choice of discursively and semantically structuring a sentence in a particular way; and the choice of intentionally or unintentionally promoting one argument or statement over others (Fairclough 2003). It examines the text 'in terms of what is present and what could have been but is not present' (Richardson 2007, 38.). As Richardson argues, 'Language is used to mean things and to do things that relate not only to the immediate context of speaker-text-audience but also to the wider socio-political, cultural and historic contexts which bound the communicative act' $(2007,25)$. In a similar manner, Gerbner (1958) explains that such crude elements of vocabulary, grammar, semantics and so on, should not be treated as reflective and insightful in themselves; rather the very idea that the function of which such elements serve when put to play is of great significance -whether such elements act to reproduce or resist systems of ideology and social power.

Representation in this paper refers to the facilitation of language in a news text or talk in order to attribute meaning to actors, their social practices, actions/events, and their social and political implications. Implicit in this view of the role of language in representation is that meaning is not only embedded in the production and reflection of reality (how things are perceived) but also, and perhaps more importantly, in the 
way reality is reproduced and construed by linguistic representation (to be a certain way) (Fairclough 2003; Wenden 2005; Richardson 2007).

\section{Data and method}

This article forms part of an extensive study that addressed the media coverage of the Gaza Conflict of 2008-2009 by exploring the Arabic and the English broadcast services of BBC and Al-Jazeera. Through quantifying certain texts in the news media and by discursively, semantically and visually analysing media messages, as well as qualitatively examining varying audiences' perceptions and reception of the war, the paper adopts a multi-method approach combing quantitative and qualitative research methods.

As suggested by Richardson and Barkho (2009) the analysis looks solely on the media representations of the protagonists' arguments and not how they are presented by the protagonists' themselves. The reason for this is that 'while the protagonist may have little restriction on how to express their own verbal and visual representations, it is important to see how far the carriers of their own arguments... are bounded in the coverage of their argumentation' (Richardson and Barkho 2009, 594). For the purpose of this paper, only excerpts germane to the provocation and proportionality of the conflict were incorporated. Thus, the analysis includes excerpts from the day before the start of the ground incursion ( $2^{\text {nd }}$ Jan 2009), the first 3 days of the ground offensive $\left(3^{\text {rd }}-5^{\text {th }}\right.$ Jan 2009) and the last 3 days of the war $\left(16^{\text {th }}-18^{\text {th }}\right.$ Jan 2009). Excerpts are numbered throughout the analysis in order to facilitate cross-referencing. Finally, the paper tries to be careful in avoiding unwarranted generalisations; commentaries made on the news' discursive procedures relate solely to the texts in question.

\section{Discussion}

\section{Provocation: Characterisation of the actors, their actions and the events that make up the conflict}

The identification of key lexical structures and terminology and their wider cultural and ideological frameworks is an important part of understanding a news corporation's discursive strategy. Whether it signals an institutional culture of power and control, or whether such discursive strategies and practices are uniform across a corporation are tricky queries to untangle in a study merely based on the analysis of texts. However, the vocabulary used for representing a certain reality (or the characterisations of actors in a certain conflict, their actions and/or events that make up this conflict) is an essential dimension of the construction of meaning (Carvalho $2010,17)$ in a news corporation's journalistic practices. Throughout the duration of the Gaza Conflict, the kind of terminology used by the BBC World Service, suggest that the channel holds certain stylistic ways of reporting the Palestinian-Israeli Conflict, as well as certain sets of lexical categories used to describe its main participants, i.e. the Palestinians and the Israelis. 
1. More than a thousand people now dead in Gaza and the fighting between Israel and Hamas militants is still escalating. (BBC World $14^{\text {th }}$ Jan 2009)

a. Heavy fighting between Israeli soldiers and Hamas militants $\left(3^{\text {rd }}\right.$ Jan, 2009)

b. In the first gun-battle between Hamas militants and the Israeli Army ( $3^{\text {rd }}$ Jan 2009)

c. Hamas the Palestinian militant group which still doesn't officially recognise the existence of Israel ( $I^{\text {st }}$ Jan 2009)

d. Rockets fired by militants inside Gaza [...] and the Israeli military have been carrying out dozens of air-strikes. ( $6^{\text {th }}$ Jan 2009)

e. Once again today Palestinian militants have been firing rockets to Israel ( $14^{\text {th }}$ Jan 2009)

It is clear from the headlines above that the portrayal of the main participants in the conflict, and their relationship to one another set up an antagonistic relationship between the two parties involved -a hero-villain, occupied-occupier or victimaggressor. In headline (1), BBC World, present the fighting as between 'Hamas militants' and 'Israel'. Throughout the duration of the conflict, Palestinian factions perpetually fell under the lexical category of 'militancy' in the BBC (ex. a-e). The BBC's reporting of the Gaza Conflict shows a substantial consistency in the syntactic position and semantic roles in the way both Palestinians and Israelis are represented as actors or participants. Examples a-e reveal that the Israeli Army is continuously being described as 'Israeli soldiers' (ex. a), 'Israeli Army' (ex. b), 'Israeli Military' (ex. d) or simply 'Israel' (ex. e) - standard terminology free of any connotations or labels. Palestinian groups, on the other hand, are almost always accompanied with epithets and labels to remind the audience of their 'militancy': 'Hamas militants' (ex. a, b), 'militants inside Gaza' (ex. d) and 'Palestinian militants', among others.

The examples above demonstrate that the BBC tends to only "re-lexicalize" and "over-lexicalize" its terminology when referring to Palestinian actors (Barkho 2010, 132). However, it is important to note, that even though BBC World persistently used the word 'militant(s)' when discussing various 'Palestinian armed factions', other negative lexical items such as 'extremists', 'fundamentalists', 'Islamists' and 'terrorists' were excluded from the coverage, unless attributed.

Was it a war against Hamas or the Palestinian population? Was it to secure Israeli security or to maintain Palestinian suffering?

It is fundamental to examine the actors' perceived influence in shaping the overall meaning of a text. In this respect questions such as, whose perspective seems to dominate, and do these actors possess the capacity to have their viewpoints represented by the journalist either in the form of quote or regular text are important for understanding the way discourse acts in constructing and deconstructing meaning in the media.

'Israel had simply no choice it had to stop the rocket attacks against Southern Israel' (Presenter-BBC World $3^{\text {rd }}$ Jan 2009') 
In the excerpt above, BBC World adopted statements issued by Israeli officials. The Israeli position that they were forced to respond to unwarranted rocket attacks by the Palestinian group Hamas, which had taken control of Gaza, was constantly emphasised on BBC World. On January 3 alone, such statements and validations were mentioned at least 10 times by presenters and correspondents verifying Israel's decision to carry out a ground incursion. Below are a few examples.

(2).Israeli infantry and tanks have now entered the Gaza Strip, Israel says it wants to control the launching sites used by militants in Gaza to launch rockets. Israel's Defence Minister Ehud Barak says Israel is determined to save its citizens (BBC World $3^{\text {rd }}$ of Jan, 2009)

(3). Some 900,000 Israelis across Southern Israel will be spending another night in re-enforced shelters fearing more attacks from the Gaza Strip. Ehud Barak said that Israel is determined to protect its citizens, he said that they had no choice but to launch those operations (BBC World $3^{\text {rd }}$ of Jan, 2009)

(4).Earlier tonight the Israeli Defence Minister Ehud Barak reiterated that Israel simply had no choice it had to stop the rocket attacks against Southern Israel (BBC World $3^{\text {rd }}$ of Jan 2009)

(5).Israel wants to take control of the sites used to fire rockets (BBC World $3^{\text {rd }}$ Jan 2009)

(6). Israel says it will do whatever it takes to stop the rocket fire (BBC World $3^{\text {rd }}$ Jan 2009)

(7).So Israel is very much defending an operation, it said that it had no choice but to launch. (BBC World $3^{\text {rd }}$ of Jan, 2009)

Examples (2)-(7) indicate that on the day of the ground incursion (Jan 3, 2009), Israeli statements were the predominant perspective adopted by BBC journalists. There is a clear evidence here of what Wodak and Fairclough call recontexualisation - in particular terms, how Israeli voices/statements/facts were taken from one context and textured and reformulated together into a new context (Fairclough 2003, 52). Take excerpt (2) for example, it suggests that Israel is under attack from militants in Gaza whom are firing rockets at Israeli towns - but wants to control those launching sites because it is 'determined to save its citizens'. Not only are Israeli citizens under attack, but 900,000 of them across Southern Israel are also under threat, so will have to spend 'another night in re-enforced shelters fearing more attacks from the Gaza Strip' (ex. (3)). Once more, BBC journalists insist that 'Ehud Barak', Israel's Defence Minister, 'is determined to protect its citizens' (ex. (3)), and 'will do whatever it takes to stop the rocket fire' (ex. (6)). Ehud Barak was reported promoting his opinions ('Ehud Barak says', 'Ehud Barak said'), reiterating them ('the Israeli Defence Minister Ehud Barak reiterated') and was shown to be 'determined' to save his citizens. Israeli statements, in this respect, are first reported but are then recontexualised as a reporting clause and paraphrase (e.g. Israel says, Israel wants, Ehud Barak said, reiterated etc.). Notice the use of the terms 'another night' and 'more rockets' which imply that it is not the first time Israeli citizens hide in reenforced shelters and that rockets are being continuously fired at Israeli towns. 
Interestingly, later on in the programme, Israeli accounts were being endorsed by the journalists; the reporting then becomes presented using existential verbs ('Israel is...') and strong modal claims ('Israel had to...'). Excerpt (7) illustrates that BBC World journalists repeated Israeli claims with strength and transparency confirming that 'Israel is very much defending an operation'. It then continues to confer, '[Israel] said it had no choice but to launch'. Claims alleging that Israel had no choice but to launch proved to be repetitive across BBC World's coverage (see ex, (3), (4) and (7)).

(8).Israel's main targets the last 24 hours have included the houses of Hamas leaders, most of them have been phoned by the Israelis and warn to get out. (BBC World $2^{\text {nd }}$ Jan 2009)

(9).Eye witnesses say that Israel is mainly targeting the homes of senior Hamas leaders (BBC World $2^{\text {nd }}$ Jan 2009)

Israeli attacks were being presented as directed only at Hamas. In a similar way, the examples above signify that 'Israel mainly targets the houses of Hamas leaders'. In the first excerpt, the journalists endorsed such claims and reported that 'Israel's main target [in] the last 24 hours have included the houses of Hamas leaders' (ex. (9)). In the second example, it presented these perspectives in the conniving voice of the 'Eye witness', which necessitates trustworthiness from the receivers' end.

What the BBC lacked in essence is explanation. Reasons to why Hamas and the Palestinians are firing rocket at Israeli towns were never touched upon, nor did they report on the perspective of the Palestinians. The Palestinian narrative which focused on the loss of their homes and land to Israel in previous wars, Israel's military occupation of Palestinian land, and more recently the siege of Gaza were also absent from the coverage. The lack of sufficient explanations on cause is critical given that it can have stern impact on audience belief and judgements (Philo and Berry 2011, 341).

\section{To whom is agency for these actions and events attributed and how?}

One way of examining a news text's syntactic features, is through syntactic transformations -that is through nominalizations, transitivity and/or active/passive sentences (Carvalho 2010, 17). Pragmatics, syntactic word order and clause structure are used to represent events, situations and interpretations in a certain way. Like vocabulary, the choices made in regards of transitivity or normal patterns represent events and narratives in certain ways desired by a given news corporation (ibid.).

(10). Civilians not connected with Hamas continued to die as well. The UN says that the people are in fear and panic and that the hospitals are overwhelmed. 3 boys including 2 brothers all from the Al-Astal family killed in a raid. (BBC World $2^{\text {nd }}$ of Jan, 2009)

(11). Hamas is still launching rockets to Israel, despite 6 days of air-raid reaching deeper than ever into the country. One struck Ashdod Israel's biggest port, and after an empty school was hit in the desert Beersheba some residents are getting out of rage. (BBC World $1^{\text {st }}$ Jan, 2009) 
The above examples are provided in order to compare the way attacks on and by both Palestinians and Israelis were reported on BBC World. As one can see from the examples above, excerpt (10) portrays the death of Palestinian civilians in Gaza; and excerpt (11) reports on rockets launched by Hamas at Israeli towns. It is worth analysing one excerpt at a time. When the casualties are Palestinians, the subject (agency or perpetrator of the action) is often not in its "normal" place at the beginning of the sentence, or in the case of excerpt (11) is completely excluded. Palestinian casualties are foregrounded being positioned at the beginning of the clause: 'Civilians not connected with Hamas'. In contrast, the Israelis, who caused the casualties, are not mentioned at all. Those civilians - perhaps even innocent civilians - were reported as 'continuing to die'. The use of the intransitive verb 'to die' proceeded by 'continued' (present continuous) does not attribute their deaths to agency and hence can be the result of anything, from a deadly earthquake to extreme poverty and hunger. In the case of this sentence, none of the process nouns are the agent of action -the grammatical subject is absent in the clause. Later in the same excerpt, other casualties were, again, reported to have been 'killed in a raid'. The employment of nominalisation in news discourse involves the 'loss' of certain semantic elements of the clause (Fairclough 2003, 143) -in the case of this example: the perpetrator who caused the deaths, or the party involved in the killing. When there is uncertainty about agency there is ambiguity about 'who does what and to whom' (Barkho 2010, 135). The practice is reversed when the attacks reported are committed by Hamas on Israeli towns. Excerpt (11) provides all necessary explanations to answer the three vital Ws: who does what to whom (ibid, 136). Who: Hamas, does what: is still launching rockets and to whom: Israel. The information in the sentence is also arranged in its "normal" order.

(12). Hello and welcome to Jerusalem it's the evening of the Jewish Sabbath. Israel says 900,000 of its citizens are living in bomb shelters tonight in fear of rockets launched by Palestinian militants in the Gaza Strip. Israel says as long as those attacks continue so will its attacks against the Gaza Strip. Those bombardments by air and attacks by navy ships of the coast of the Gaza Strip have continued for a $7^{\text {th }}$ day. (BBC World $2^{\text {nd }}$ of Jan, 2009)

The use of emotive language in reporting a dispute creates easy gateways for audiences to attribute agency to the party they consider holds more responsibility. Associations and familiarity are crucial aspects in determining culpability. The excerpt above adopts Jewish sentiments and reports: on 'the evening of the Jewish Sabbath, 900,000 Israeli citizens are living in bomb shelters in fear of rockets launched by Palestinian militants in the Gaza Strip'. It is suggested that when perpetrators appear at the end of a clause, they automatically 'lose' the focus or "thematic prominence"...as the ones who are responsible' (Barkho 2010, 135). However, the example above illustrates that Israeli civilians are 'in fear' of those rockets launched by 'militants'. So rather than downgrading the level of attribution, Hamas are being presented as causing fear amongst the Israeli civilian population and are -as already established -being depicted as militants. It then adopts the 'as long as those attacks continue so will its attacks against the Gaza Strip' which suggests that Israeli attacks are acts of retaliation. Similar patterns in reporting Israeli attacks against Gaza are evident in excerpt (32). Israeli bombardments by air and attacks by navy ships are reported to 'have continued for a $7^{\text {th }}$ day' with references to the 
perpetrator being omitted entirely. The use of nominalisation, in this respect, generalises events and abstracts those involved from agency.

\section{Proportionality: War Crimes, Causalities and Humanitarian Suffering}

BBC World's discursive strategy in covering Israel's use of white phosphorus implies a rather different stance. Such an anomaly in BBC's reporting reflects the network's inconsistency in justifying yet attributing blame to the Israeli army's deployment of prohibited munitions in its war on Gaza. Since the BBC first reported Israel's use of white phosphorus almost a week after Israel's ground incursion, BBC World shifted their public position on the issue from justifying and rationalising its use, to openly accusing Israel of violating International Law.

In one of the first instances in which White Phosphorus (WP) was reported on BBC World, Ben Brown, one of the networks leading correspondents, maintained that Israel's use of white phosphorus comply with International law. White phosphorus is not banned per se, but rather like all other weapons its use is 'restricted by the fundamental principles of international humanitarian law: it must be used in a manner that adequately distinguishes between combatants and civilians, and it may never target the latter' (Human Rights Watch 2009, 3). Brown reports:

As darkness fell this evening, the artillery were firing white phosphorus shells into Gaza to provide smokescreen for ground troops to carry out operations there under cover of darkness. We've also seen tanks advancing in certain positions and firing above us. We've had Israeli apache helicopters opening fire with their $30 \mathrm{~mm}$ cannon (BBC World $9^{\text {th }}$ Jan 2009)

The use of white phosphorus in this domain is justified, rationalised and deemed acceptable. The correspondent does not adopt clauses that reads; 'Israel said', 'Israel claims' or 'according to Israeli sources'; rather it firmly reports that Israel's use of white phosphorus is 'to provide smokescreen for ground troops to carry out operations there [Gaza] under cover of darkness'. Here, BBC World admits Israel is using white phosphorus in Gaza but its use is deemed legitimate and obligatory for the military to carry out its operation and, furthermore, that the use of WP in this context has no bearing on the civilian population of Gaza.

On January 15, BBC World's position regarding Israel's legitimacy of its use of weapons began to shift. On that day, the United Nations headquarters was hit by two artillery shells in a crowded urban area, injuring three civilians and leaving the compound's main warehouse burned to the ground (McCarthy 2010). In a report dedicated to the incident, a BBC journalist explained:

The UN has condemned the shelling of a UN compound in Gaza city; the attack left desperately needed food and medicine ablaze. The UN relief agency in Gaza said it believes the compound was hit by white phosphorus shells: incendiary weapons used to create smoke screens which mustn't be used in civilian areas... Israel says it uses this weapon legally, Human Rights campaigners disagree 
For the first time, BBC World acknowledges that Israel's use of white phosphorus could be improper. It claims that the deployment of incendiary weapons, like white phosphorus, 'mustn't be used in civilian areas'. It explains that Israel maintains that it uses this weapon 'legally', but immediately dismisses this claim by indicating that 'Human Rights campaigners disagree'.

Hall et al.'s model of 'primary definition' (1978), assumes that the viewpoints of those in powerful positions in society - primary definers - Israel in the case of this study, are accepted and to a certain extent endorsed by the media. Such a structured relationship between the media and the primary institutional definers, 'permits the institutional definers to establish the initial definition or primary interpretation of the topic in question' (Hall et al. 1978, 58). After such a framework of interpretation is established, it effectively frames the problem at stake. The media -acting as secondary definers -then, do not simply transmit the ideology of the powerful, but play a crucial but secondary role in reproducing these definitions and in evaluating such interpretations. This conflicts with findings drawn from the analysis and suggests a more radical pluralist approach, which argues that a more processual model is needed to understand the dynamics of news creation. The analysis shows that when the controversy of the unlawful use of white phosphorus is highlighted and the proportionality of suffering and despair is reported the legitimacy attributed to Israeli policies is shown to be eroded. The tools employed to portray the suffering inflicted on civilian casualties, shift attention away from the initial interpretive framework of "what is at stake" and begin to emphasise on the significance and legitimacy of such definitions.

\begin{tabular}{|c|c|}
\hline Correspondent & $\begin{array}{l}\text { Marc Garlasco }[\ldots] \text { the Israeli government they say they are using } \\
\text { it within the scope of the International Law and we do see many } \\
\text { militaries worldwide using white phosphorus }\end{array}$ \\
\hline $\begin{array}{l}\text { Marc } \\
\text { Garlasco }\end{array}$ & $\begin{array}{l}\text { That's correct but what we are seeing in Gaza right now is the use } \\
\text { of white phosphorus in densely populated areas which is a violation } \\
\text { of the Geneva Convention. I stand everyday on the border watching } \\
\text { as dozens upon dozens of white phosphorus artillery in an air-burst } \\
\text { situation falling at the Jabalya Refugee Camp and Gaza city raining } \\
\text { down fire on the civilians there. We, Human Rights Watch, } \\
\text { consider this to be a violation of the Geneva Convention. }\end{array}$ \\
\hline Correspondent & $\begin{array}{l}\text { And why is that what damage does it do to civilians, what's the } \\
\text { harm caused? }\end{array}$ \\
\hline Marc Garlasco & $\begin{array}{l}\text { Well when the flames come out of the white phosphorus shells and } \\
\text { descend over } 250 \text { meters radius area they ignite and they can cause } \\
\text { severe burns } 3^{\text {rd }} \text { degree they also can light homes on fire and as } \\
\text { we've seen today at the United Nations was burnt by the White } \\
\text { phosphorus. So we are calling on Israel to cease the use of white } \\
\text { phosphorus in these densely populated areas of Gaza }\end{array}$ \\
\hline Correspondent & $\begin{array}{l}\text { Marc Garlasco, Human Rights Watch thank you very much for } \\
\text { joining us here. }\end{array}$ \\
\hline
\end{tabular}

Figure 1: Interview with Marc Garlasco (Human Rights Watch - Weapons expert) - $15^{\text {th }}$ Jan 2011 
Following the report, BBC World's correspondent at the Israel-Gaza border conducted a face-to-face interview with Marc Garlasco from Human Rights Watch. Figure 1 presents a detailed transcription of the encounter.

Firstly, the correspondent's initial question highlights the Israeli government's statement that 'they are using [white phosphorus] within the scope of the International Law', and secondly, such use is rationalised and justified by the correspondent as being used worldwide by many militaries. The use of the phrase "we do see' confirms such a statement which connotes notions of factuality and truthfulness to the matter. It also includes Garlasco himself and the audience and suggests that they all have seen 'many militaries worldwide using white phosphorus' - implying that Israel's use of phosphorus bombs is 'legitimate'. Garlasco explains that what has been said is correct but indicates that 'what we are seeing in Gaza right now is the use of white phosphorus in densely populated areas which is a violation of the Geneva Convention'. He adopts similar strategies to those of the correspondent and asserts that his statements are based on direct observation and scrutiny. Garlasco not only has stood on the borders 'everyday watching as dozens upon dozens of white phosphorus artillery round burst of the Jabalya Refugee Camp and Gaza city', but he also witnessed phosphorus shells 'raining down fire on the civilians there'. This, regardless of Israeli claims is considered 'a violation of the Geneva Convention' with accordance to Human Rights Watch.

Seen from an 'emotionalism' perspective, Garalsco is made to signify the 'damage' and 'harm' white phosphorus munitions have on civilians. From this, it is clear that the correspondent accepts Garlasco's claims that it is affecting the civilian population. White phosphorus shells are thus reported to form flames that 'descends over 250 meters radius area they ignite and they can cause severe burns third degree' and are also capable of 'lighting homes on fire' as was the case at the United Nations headquarters. To get an alternative perspective, BBC World also conducts a face-to face interview with Yigal Palmor, the Israeli Foreign Ministry spokesperson. A detailed transcription of the interview is provided in Figure 2 below.

\begin{tabular}{l|l} 
Presenter: & $\begin{array}{l}\text { Let's now talk to the Israeli government about these comments, we are } \\
\text { joined here by Foreign Ministry spokesman Yigal Palmor, Yigal I'll first } \\
\text { start with Human Rights Watch it says that it is a violation of the } \\
\text { Geneva Convention to use white phosphorus in built-up areas, is that } \\
\text { Yomething you as diplomat recognise? }\end{array}$ \\
\cline { 2 - 3 } Yigal: & $\begin{array}{l}\text { I think what I would like to quote now is what the ICRC said yesterday } \\
\text { or the day before Peter Herbly who is responsible for the ICRC for arms } \\
\text { control said clearly and in public that he had no evidence whatsoever of } \\
\text { any illegal use by Israel of white phosphorus. I think that is quite clear, } \\
\text { he made some more comments to elaborate on that but I think that those } \\
\text { words are very clear and they need to be carried to the Human Rights } \\
\text { Watch and to the other Human Rights organisations because they need } \\
\text { to take heat of what the ICRC have said }\end{array}$ \\
\cline { 2 - 3 } $\begin{array}{l}\text { Perhaps they were speaking before the Israeli forces moved so deep into } \\
\text { crowded areas like Gaza city. I know you used white phosphorus when } \\
\text { you first went in to the Gaza Strip two and a half weeks ago in open } \\
\text { areas but now that civilians are being put in harms-way Human Rights }\end{array}$ \\
\hline
\end{tabular}




\begin{tabular}{l|l}
\cline { 2 - 2 } Yigal: & $\begin{array}{l}\text { Watch and others say this is a violation it is bringing harm to civilians } \\
\text { again everything the IDF does is under International Law, we don't use } \\
\text { any munitions we don't use any weapons that are not used by any other } \\
\text { Western democratic countries and we use them in exactly the same way } \\
\text { or to put it more simply everything that the international law allows is } \\
\text { what we do, everything that international law prohibits we don't do. }\end{array}$ \\
\hline
\end{tabular}

Figure 2: Interview with Yigal Palmor (Foreign Ministry Spokesman) - 15 ${ }^{\text {th }}$ Jan 2011

Although the exchange presented in Figure 2 above is identical in structure to the two-way interview with the source from Human Rights Watch (HRW), there are two apparent differences in the encounters presented in Figures 1 and 2. First, Yigal, the Israeli Foreign Ministry spokesperson, appears to dodge the question asked to him both times in which the journalist formulates the opinion of the interviewee's opponent. Such approach implies evasiveness and ambiguity on Yigal's behalf, allowing him to surpass the matter in question. Second, the journalist arguably challenges Yigal's argument, accusing him of being selective - only referencing sources that are in line with their own claims. Yigal's response to accusations directed at Israel of violating the Geneva Convention assumes a defensive approach. Rather than justifying Israeli actions by providing concrete evidence proving that Israel is not at fault, Yigal cites the ICRC (International Committee of the Red Cross) declaring Israel innocent. Yigal's utter confidence in the ICRC's statements is only granted given it supports the Israeli claim. This is highlighted when Yigal explains that 'those words are very clear and [...] need to be carried to the Human Rights Watch and to the other Human Rights organisations', which suggests that although Human Rights organisations are equally trusted as the ICRC yet Yigal only quotes organisations that place Israel in good light. Interestingly, the BBC World's journalist offers reasons to why the ICRC would issue such statements; she questioned: 'Perhaps they were speaking before the Israeli forces moved so deep into crowded areas like Gaza city'. The journalist, here, presents an explanation regarding the difference between the information provided by HRW and ICRC and therefore, implicitly, accuses Yigal of being selective with evidence. She then elaborated saying 'I know you used white phosphorus when you first went in to the Gaza Strip two and a half weeks ago in open areas' which of course, as already established, is a legitimate use. However, she explains, 'now that civilians are being put in harms-way, Human Rights Watch and others say this is a violation it is bringing harm to civilians'. Yigal's assertion that 'everything the IDF does is under International Law' is a statement of principle indicating that Israel 'doesn't use any munitions that are not used by other Western democratic countries'. Again, Yigal justifies Israel's actions by comparing them to that of 'Western democratic' countries. It suggests that whatever is acceptable for the US and UK must also be deemed legitimate to Israel.

\section{Conclusion}

It is hoped that a contextualised account of television reporting during Operation Cast Lead, is able to act as the basis for understanding the role of new forms of media outlets such as Digital and Social media. The impartiality and bias utilised in mainstream media have paved the way for a new form of reporting via social media platforms - be it User Generated Content (UGC), first hand reporting, investigative journalism or general reporting. 
This paper, however, attempted to provide a political and historical context to the recent conflict in the Gaza Strip. It is hoped that the semantic and discursive analysis revealed here will allow for a better understanding of war reporting generally and the Palestinian-Israeli Conflict more specifically.

One particularly significant finding that emerged from the analysis, suggests that while the provocative aspect of the war formulated interpretations and explanations as to why the war took place, who provoked it and whose fault it was, which consequently developed a basic awareness and understanding, placing the conflict within a contextual framework; analysing the humanitarian aspect of the war provided evaluations to whether such acts are deemed legitimate -to whether civilian suffering is a 'legitimate' outcome of war. The analysis revealed that it may well be the case that, in some instances, the actions of a protagonist may be deemed legitimate with regard to provocation, but illegitimate with regard to their proportionality.

Given the interpretive structure of the analysis has charted the problem at stake and generated understandings of culpability and blame, the evaluative structure initially suggests that the media did play a primary role in evaluating those dominant frames. Unlike with provocation, legitimacy attributed to Israeli policies is shown to be eroded when the proportionality of suffering and despair is reported. The verbal drift away from the initial interpretive framework of "what is at stake" and start to highlight the implications and legitimacy of such meanings and ideologies.

The provocation data suggests that the BBC broadly bought the Israeli argument that they were forced to respond to unwarranted rocket attacks by Hamas. However, as the scale of the violence became more evident, this interpretation became vulnerable at an evaluative level. In other words, the Israeli actions came to be seen as disproportionate in their violence. Israel may have set the terms of the argument at the outset, but as the war progressed, such argument started to lose credibility. These findings urge us to look beyond an overview analysis of war reporting, necessitating the need for a comprehensive context-related evaluations.

\section{References}

Barkho, L. (2010) 'The BBC'S Discursive Strategy and Practices vis-à-vis the Palestinian-Israeli Conflict'. In Language and Journalism 9 (2): 278-294.

Belsey, A. and Chadwick, R. (1992) 'Ethics and Politics of the Media: the Quest for Quality' in Belsey, A. and Chadwick, R. (eds.) Ethical Issues in Journalism and the Media. London: Routledge.

Berkowitz D. (1997) 'Refining the Gatekeeping Metaphor for Local Television News' in Berkowitz D. (ed.) Social Meanings of News: A Text Reader. London: SAGE. 
Bird, S. E. and Dardenne, R. W. (1997) 'Myth, Chronicle and Story: Exploring the Narrative Qualities of News' in Berkowitz D. (ed.) Social Meanings of News: A Text Reader. London: SAGE.

Cameron, D. (2001) Working with Spoken Discourse. London: Sage.

Carvalho, A. (2010) 'Media(ted) Discourse and Society: Rethinking the framework of Critical Discourse Analysis'. In Language and Journalism 9(2): 10-26.

Eldridge, J. (1995) 'Ill news comes often on the back of worse', in Eldridge, J. (ed.) Glasgow Media Group Reader Volume 1: News Contents, Language, and Visuals. London: SAGE Publications

Ettema, J. S., Whitney D. C., with Wackman D. B. (1997) 'Professional Mass Communicators' in Berkowitz D. (ed.) Social Meanings of News: A Text Reader. London: SAGE.

Fairclough, N. (1993) 'Critical Discourse Analysis and the Marketization of Public Discourse: The Universities'. In Discourse and Society 4 (2): 133-168

Fairclough, N. (2003) Analysing Discourse: Textual Analysis for Social Research. London: Routledge.

Fairclough, N. and Wodak, R. (1997) Critical Discourse Analysis: An overview, in T.A. van Dijk (ed.) Discourse Studies: A Multidisciplinary Introduction, Vol. 2, pp. 67-97. London: Siege

Gerbner, G. (1958) 'On content analysis and critical research in mass communication' in L. A. Dexter and D. Manning (eds.) (1964) People, Society and Mass Communications, pp. 467-500. New York: Free Press.

Gitlin, T. (1979) 'Prime Time Ideology: The Hegemonic Process in Television Entertainment' in Social Problems, Vol. 26, No. 3. (Feb., 1979), pp. 251-266.

Hall, S. (1977) 'Culture, the Media and the "Ideological Effect'. In Curran J., Gurevitch M. \& Woollacott, J. (Eds.), Mass Communication and Society. London: Edward Arnold

Hall, S., C. Critcher, T. Jefferson, J. Clarke and B. Roberts (1978) Policing the Crisis. London: Macmillan

Human Rights Watch (2009) 'Rain on Fire: Israel's Unlawful use of White Phosphorus in Gaza' Human Rights Watch. March 2009. Available at: http://www.hrw.org/sites/default/files/reports/iopt0309webwcover.pdf [Accessed Oct. 5th 2010] 
lyengar, S. (1991). Is anyone responsible? How television frames political issues. Chicago, IL: University of Chicago Pres

McCarthy, R. (2010) 'UN find challenges Israeli version of attack on civilian building in Gaza war'. The Guardian, (February, $\left.1^{\text {st }} 2010\right)$. Available at: http://www.guardian.co.uk/world/2010/feb/01/gaza-war-report-accuses-israel

Molotch, H. and Lester, M. (1997) 'News as Purposive Behaviour: On the Strategic Use of Routine Events, Accidents and Scandals' in Berkowitz D. (ed.) Social Meanings of News: A Text Reader. London: SAGE.

Murdock, G. (1982): 'Large Corporations and the Control of the Communications Industries'. In Gurevitch, M., Bennett, T., Curran, J., and Woollacott, J. (eds.), Culture, Society, and the Media. London: Methuen.

Philo, G. and Berry, M. (2011) More Bad News from Israel, London: Pluto Press

Reese, Stephen D. (1997) 'The News Paradigm and the Ideology of Objectivity: A Socialist at the Wall Street Journal' in Berkowitz D. (ed.) Social Meanings of News: A Text Reader. London: SAGE.

Richardson, J.E (2007) Analysing Newspapers: An Approach from Critical Discourse Analysis. Palgrave Macmillan.

Richardson, J. E. and Barkho, L. (2009) 'Reporting Israel/Palestine: the verbal and visual rhetoric of BBC journalism'. In Journalism Studies 10 (5): 594-622.

Schudson, M. (1978). Discovering the News. New York: Basic Books, Inc.

Schudson, M. (2001). 'The objectivity norm in American journalism'. Journalism, 2(2), 149-170

Shoemaker, P. J. (1997) 'A New Gatekeeping Model' in Berkowitz D. (ed.) Social Meanings of News: A Text Reader. London: SAGE.

Soloski, J. (1997) 'News Reporting and Professionalism: Some Constraints on the Reporting of the News' in Berkowitz Dan Social Meanings of News: A Text Reader. London: SAGE.

Tuchman, G. (1972) 'Objectivity as a strategic ritual: an examination of newsmen's notions of objectivity', in American Journal of Sociology, vol. 77: 660-79

Tumber, H. (2004) 'Prisoners of news values?: Journalism, professionalism, amd identification in times of war' in Allan, S. and Zielzer, B. (eds.) Reporting War: Journalism in Wartime. London: Routledge 
Wenden, A.L. (2005) 'The Politics of Representation: A Critical Discourse Analysis of an AlJazeera Special Report' in International Journal of Peace Studies. 10 (2): 89-112

Wodak, R. and Meyer, M. (eds.) (2001) Methods of Critical Discourse Analysis. London: Sage.

Nour Shreim is a $\mathrm{PhD}$ graduate from the Department of Social Sciences at Loughborough University and is currently a Research Manager at Livestation Ltd. Her research focuses on discourse, news reporting and reception, with a particular interest in Arab media.

Email: n.shreim1@gmail.com 